\title{
Genetic basis of hypertension for the development of tailored medicine
}

\author{
Tomohiro Katsuya ${ }^{1}$, Ryuichi Morishita ${ }^{1}$, Hiromi Rakugi ${ }^{2}$ and Toshio Ogihrara ${ }^{3}$ \\ Similar to a tsunami wave, a new surge of genome-wide association studies in common complex diseases has succeeded in \\ identifying the causative genetic risk factors of hypertension. The current status of genomic studies in hypertension, however, \\ remains disorganized, and there are no clear solutions in sight. One possible reason for this disorganization is the small effect \\ of each genetic variant on the predisposition to hypertension. Another reason could be that the morbidity of hypertension is \\ typically used as a target to assess genetic contribution, which could be resolved by introducing new technology into the \\ classical genetic analysis. In this review, we reaffirm the genetic basis of hypertension and outline recent progress in genomics. \\ In addition, we discuss both the possibility and usefulness of genomic information in the development of tailored medicine. \\ Hypertension Research (2009) 32, 643-648; doi:10.1038/hr.2009.87; published online 19 June 2009
}

Keywords: gene; GWAS; pharmacogenomics; polymorphism; salt sensitivity

\section{INTRODUCTION}

In Japan, physicians frequently refer to the guidelines of hypertension in daily clinical practice. The latest version of the guidelines was recently published by the Japanese Society of Hypertension (JSH2009). ${ }^{1}$ The number of hypertensive patients in Japan was estimated to be $\sim 40$ million. It was also found that a $2 \mathrm{~mm} \mathrm{Hg}$ decrease in systolic blood pressure (BP) led to a $>5 \%$ decrease in the occurrence of stroke or ischemic heart disease. Thus, there is no question that the primary goal of hypertension treatment is to prevent cardiovascular disease by achieving a specific BP level. The response to antihypertensive treatment and the grade of targeted organ damage vary significantly among individuals, and the standard therapy described in the guidelines does not always achieve the final goal of treatment. A reason for this diversity is that a large proportion of hypertension cases are essential hypertension, of which the cause is not yet defined. This indicates that the identification of certain causes or predisposing factors for hypertension could lead to the development of more specific and efficient treatments. For example, if physicians could diagnose 'salt-sensitive hypertension' accurately, a reduction in the dietary intake of salt and a small dose of diuretics should be prescribed with confidence. In this study, we review publications with regard to the genetic basis of hypertension and discuss the clinical application of the results.

\section{HERITABILITY OF BP}

Both genetic and environmental factors are involved in the pathogenesis of hypertension. The genetic factors contribute to approximately
$30-70 \%$ of disease susceptibility. The proportion of hypertensive patients with affected siblings was studied in 6000 Caucasian patients, ${ }^{2}$ showing a recurrence risk of $\sim 3.5$ for hypertension. The heritability $\left(\mathrm{H}^{2}\right)$ of systolic and diastolic BP in 6148 Sardinians was estimated to be $0.253(0.156-0.651)$ and $0.186(0.121-0.449)$, respectively. ${ }^{3}$ As aging has been found to be the most influential on BP in covariate analysis, the effect of genetic factors should be discussed after adjusting for age.

Previous studies with regard to monogenic hypertension and hypotension showed the importance of rare genetic variations in the electrolyte channels and transporters of renal tubules (Table 1). It is interesting that the same gene, such as the one encoding the $\beta$ - and $\gamma$-subunit of the epithelial sodium channel $(S N C C 1 B / G)$, contributes to both hypertension (Liddle's syndrome) and hypotension (pseudohypoaldosteronism type 1, or PHA1), depending on the mutation. The importance of rare genetic variations receives significant attention not only in cases of monogenic hypertension/hypotension but also in essential hypertension. In the Framingham Heart Study, rare genetic variations in three genes, solute carrier family 12 member 3(SLC12A3) (thiazide-sensitive Na-Cl co-transporter, TSC), SLC12A1 (NKCC2) and KCNJ1 (ROMK), were found to be associated with lower BP in the general population. ${ }^{4}$ Thus, rare genetic variations may explain, at least in part, the complex genetics of human hypertension. ${ }^{5}$ In JSH2009, Table 12-7 lists information regarding rare genetic variations in essential hypertension and includes a list of congenital diseases with BP abnormalities, the name of the causative genes and their clinical features. ${ }^{1}$

${ }^{1}$ Department of Clinical Gene Therapy, Osaka University Graduate School of Medicine, Suita, Japan; ${ }^{2}$ Department of Geriatric Medicine, Osaka University Graduate School of Medicine, Suita, Japan and ${ }^{3}$ Osaka General Medical Center, Osaka, Japan 


\section{SALT SENSITIVITY AND GENETIC PREDISPOSITION TO HYPERTENSION}

The most popular approach to identifying hypertensive genes involves genetic association studies, which are population-based and compare cases and controls. The candidate gene approach is a classical but powerful method to examine the predisposing genetic factor of hypertension. Many studies have examined the association between gene variants of the renin-angiotensin system and hypertension. Among these, M235T, T174M and G-6A polymorphisms of the angiotensinogen gene (AGT) have been determined to increase the genetic risk not only for hypertension but also for ischemic heart disease, ${ }^{6}$ lacunar infarction and non-dipper type of BP variation. ${ }^{7}$ These results suggest the possibility that a polymorphism in AGT modulates the sensitivity to salt through an enhancement of sympathetic nerve activity or insulin resistance, thereby increasing the risk for ischemic heart disease. Indeed, $A G T$ is considered to be a thrifty gene that has the advantage of surviving in a harsh environment; however, it increases the risk for cardiovascular disease through sodium and body fluid retention. In addition to $A G T$, the risk allele frequencies of popular candidate gene polymorphisms of salt-sensitive hypertension, such as alpha adducin (ADD1), the G-protein beta-3 subunit gene (GNB3) and the aldosterone synthase gene (cytochrome $\mathrm{P} 450$, subfamily Y XIB, polypeptide 2, CYP11B2), are higher in the Japanese population than in Caucasians. ${ }^{8}$ Hunt et al. ${ }^{9}$ reported that the effect of salt reduction and weight loss on the prevention of hypertension in pre-hypertensive individuals with the risk allele was much greater than in individuals with the normal allele. Therefore, a reduction in salt or a small dose of diuretics should be an effective approach in the treatment of hypertension in Japanese patients. On the basis of the comparable effectiveness for the treatment of hypertension and the advantage of pharmaco-economics, JSH2009 encourages physicians to use diuretics more frequently.

The thiazide-sensitive $\mathrm{Na}-\mathrm{Cl}$ co-transporter has an important function in the treatment of hypertension with diuretics. Kokubo et al. ${ }^{10}$ and our group ${ }^{11}$ have reported a positive association between the TSC gene (SLC12A3) and a predisposition to hypertension. Matayoshi et al. ${ }^{12}$ showed that the C1784T polymorphism of SLC12A3 was significantly associated with the antihypertensive effect of diuretics. As a functional single-nucleotide polymorphism (SNP) of SLC12A3, Keszei et al. ${ }^{13}$ showed the difference in renal tubular sodium transport by an Arg919Cys substitution of SLC12A3, using the Xenopus laevis oocyte expression system. The TSC gene not only indicates a genetic risk for hypertension but is also a causative gene for monogenic hypotensive disease (Gitelman's syndrome) ${ }^{14}$ (Table 1).

Molecules with similarly important functions in salt homeostasis are WNK kinases (WNK1 and WNK4), which are also causative genes for monogenic hypertension with hyperkalemia (Gordon's syndrome $)^{15}$ (Table 1). WNK kinases bind and phosphorylate two Ste20-related protein kinases, OSR1 and STK39, which bind and phosphorylate TSC to increase their activity. This results in WNK kinases modulating the electrolyte and water transport pathways in the distal nephron. ${ }^{16,17}$ A recent genome-wide association study (GWAS) in Amish and non-Amish Caucasians showed strong association signals with common variants in STK39, a serine/threonine kinase gene. STK39 interacts with WNK kinases and cation-chloride cotransporters, mutations of which cause monogenic forms of BP dysregulation. ${ }^{18}$ This indicates that TSC, STK39, OSR1 and WNK kinases are key molecules in the pathogenesis of hypertension and are the new targets of treatment for hypertension.
Table 1 Genes involved in monogenic hypertension and hypotension

\begin{tabular}{|c|c|c|}
\hline Locus & Gene symbol & Diseases \\
\hline \multicolumn{3}{|c|}{ Monogenic hypertension } \\
\hline $4 p 31.1$ & NR3C2 & $\begin{array}{l}\text { Early-onset hypertension with severe } \\
\text { exacerbation in pregnancy }\end{array}$ \\
\hline $8 q 21$ & CYP11B1 & $\begin{array}{l}\text { Adrenal hyperplasia due to } 11-\beta \text {-hydroxylase } \\
\text { deficiency }\end{array}$ \\
\hline $8 q 21$ & CYP11B1\&2a & Glucocorticoid-remediable aldosteronism (GRA) \\
\hline $10 q 24.3$ & CYP17 & 17- $\alpha$-hydroxylase/17, 20-lyase deficiency \\
\hline $12 \mathrm{p} 13$ & WNK1 & Gordon's syndrome (PHA IIC) \\
\hline 16p13-p12 & $S C N N 1 B / G$ & Liddle's syndrome \\
\hline $16 q 22$ & HSD11B2 & Apparent mineralocorticoid excess (AME) \\
\hline $17 q 21-q 22$ & WNK4 & Gordon's syndrome (PHA ॥B) \\
\hline \multicolumn{3}{|c|}{ Monogenic hypotension } \\
\hline $1 \mathrm{p} 36$ & $C L C N K B$ & Bartter's syndrome, type 3 \\
\hline $1 p 31$ & $B S N D$ & Bartter's syndrome, type 4 \\
\hline $4 p 31.1$ & NR3C2 & $\begin{array}{l}\text { Pseudohypoaldosteronism, type } 1 \text {, autosomal } \\
\text { dominant (PHA1) }\end{array}$ \\
\hline $11 q 24$ & KCNJ1 & Bartter's syndrome, type 2 \\
\hline $12 \mathrm{p} 13$ & SCNN1A & $\begin{array}{l}\text { Pseudohypoaldosteronism, type } 1 \text {, autosomal } \\
\text { recessive (PHA1) }\end{array}$ \\
\hline $15 q 15-q 21.1$ & $S L C 12 A 1$ & Bartter's syndrome, type 1 \\
\hline 16p13-p12 & $S C N N 1 B / G$ & $\begin{array}{l}\text { Pseudohypoaldosteronism, type } 1 \text {, autosomal } \\
\text { recessive }(\mathrm{PHA} 1)\end{array}$ \\
\hline $16 q 13$ & $S L C 12 A 3$ & Gitelman's syndrome \\
\hline
\end{tabular}

CYP11B1\&2, cytochrome P450, subfamily Y XIB, polypeptide 1\&2; PHA,

pseudohypoaldosteronism; $S L C 12 A 1$, solute carrier family 12 member 1; SLC12A3, solute carrier family 12 member 3 .

${ }^{a}$ GRA is caused by chimeric gene in which the $5^{\prime}$-regulatory sequences of the CYP11B1 are fused to the coding region of the CYP11B2.

\section{GENETIC BASIS FOR HYPERTENSION}

Blockade of the renin-angiotensin system improves not only hypertension but also insulin sensitivity and adipocytokine abnormalities. ${ }^{19}$ The recent TROPHY trials ${ }^{20}$ suggested that an early blockade of the renin-angiotensin system prevents the onset of hypertension. High normal BP, obesity and impaired glucose tolerance are independent predictors of the onset of hypertension. ${ }^{21} \mathrm{BP}$ was shown to be significantly associated with lower adiponectin concentrations, regardless of insulin resistance. In individuals with a TC genotype of an I164T polymorphism of the adiponectin gene (ADIPOQ), adiponectin concentrations were one-third the normal level in individuals who had the homozygous wild allele. Moreover, these individuals were highly predisposed to cardiovascular diseases. $^{22}$

Endothelial dysfunction due to reactive oxygen species (ROS) is also considered to be a cause of hypertension. ${ }^{23}$ The genetic variants of the endothelial nitric oxide synthase gene (NOS3) have been determined to increase the genetic risk for coronary spasms ${ }^{24}$ and to increase pulse pressure and senile cognitive dysfunction. ${ }^{25}$ The C677T polymorphism of the methyleneteterahydrofolate reductase (MTHFR) gene was also found to be significantly correlated with hyperhomocysteinemia and carotid atherosclerosis in Japanese women, and the significance increased when the women smoked. ${ }^{26}$ Thus, in individuals who are genetically sensitive to ROS, a recommendation to cease smoking and to modify lifestyle, or drug administration to reduce oxidative stress, should be given. Recent pharmacological studies have shown that the combination of pioglitazone and candesartan exerts more beneficial effects on hypertensive cardiovascular damage by increasing the suppression of ROS. ${ }^{27}$ 
The modulation of sympathetic nerve activity has a key function in the pathogenesis of cardiovascular diseases. We reported in a 5-year longitudinal study that beta2-adrenergic receptor gene (ADRB2) polymorphisms in association with exaggerated sympathetic nerve activity could predict the future onset of obesity and hypertension. ${ }^{28}$ Furthermore, higher plasma norepinephrine levels that are associated with $\beta 2$-adrenoceptor polymorphisms predict future renal damage in nonobese, normotensive individuals. ${ }^{29}$ Leptin is another unique molecule to be considered as the common denominator between obesity and problems in the sympathetic nervous system. We have also pointed out that leptin-receptor gene (LEPR) polymorphisms have a function in the development of obesity through leptin resistance and blunted leptin-mediated sympathetic nerve activity. ${ }^{30}$ As the Gly16 allele of $A D R B 2$ polymorphisms is linked to weight gain-induced BP elevation and is associated with leptin resistance, ${ }^{31}$ the genotype information of adrenoceptors and leptin receptor gene polymorphisms may be useful for determining optimal diet and exercise.

RECENT PROGRESS OF GWASS IN HYPERTENSION GENETICS In recent years, GWASs have surpassed classical genetic investigations using a candidate gene approach. First, a result obtained from the Wellcome Trust Case Control Consortium (WTCCC) using 14000 cases of 7 common diseases and 3000 shared controls was published in Nature in 2007. ${ }^{32}$ Even though hypertension was included in the seven major diseases, no significant independent associations were detected in cases of hypertension. This was in contrast to diabetes, Crohn's disease, rheumatoid arthritis and coronary artery disease. Only haplotype analysis showed a marginal association with hypertension on the 15q26.2 locus, but this was unable to pass WTCCC's stringent genotype quality filters. ${ }^{33}$ Ehret et al. carried out a replication study using the top six SNPs from the WTCCC data in 11433 individuals from the US National Heart, Lung, and Blood Institute-funded Family Blood Pressure Program. They found that only one SNP, rs1937506, was significantly associated with hypertension; however, its location was in a $500-\mathrm{kb}$ gene desert on $13 \mathrm{q} 21 .^{34}$ In the Hypertension Genetic Epidemiology Network, Shi et al. examined gene-age interactions using genome-wide linkage analysis. The highest logarithm of odds score was identified on the chromosomal region 1p36, and supporting evidence was confirmed in three separate studies. This investigation also showed that genetic effects on BP varied by age. ${ }^{35}$

The Japanese Millennium Genome project succeeded in identifying several loci and genes responsible for hypertension. In this project, Japanese researchers shared the samples and examined the genetic variants using 18977 microsatellite markers and 80795 SNPs. This resulted in 19 allelic loci using the microsatellite approach, ${ }^{36}$ and 3 genes using the SNP approach ${ }^{37}$ were identified as susceptible genes for hypertension. The genes identified were the beta-adducin gene $(A D D 2)$ on 2p14-p13, KIAA0789 on $12 \mathrm{q} 23.3$ and the mannose6-phospate gene (M6PR) on 12p13.

Recently, a GWAS in the Kooperative Gesundheitsforschung in der Region Augsburg (KORA) S3 cohort study of 1644 Germans showed a significant association between BP and a common variant, rs11646213, upstream of $\mathrm{CDH} 13$. This gene encodes for an adhesion glycoprotein QJ;T-cadherin, a regulator of vascular wall remodeling and angiogenesis. $^{38}$ The significant association was reconfirmed in KORA S4 (Germans) and HYPEST (Estonians), and a similar trend was observed in BRIGHT (British). It is interesting that T-cadherin is also a receptor for the hexameric and high-molecular-weight species of adiponectin, but not for the trimeric or globular species. ${ }^{39}$ In addition, methylation of the promoter region of $\mathrm{CDH} 13$ was found to be significantly associated with the recurrence of non-small-cell lung cancer. ${ }^{40} \mathrm{~A}$ similar association was observed in the cyclin-dependent kinase inhibitor $2 A$ gene $(C D K N 2 A)$ on 9 p21, a current interest as the candidate locus of myocardial infarction. ${ }^{41}$ These results indicate that the genes considered to be candidates for tumorigenesis or metastasis also act as the modifiers of vascular remodeling, atherosclerosis and metabolic signals.

Another recent breakthrough of the GWAS in hypertension appeared as three articles in an issue of Nature Genetics. ${ }^{42-44}$ The first paper ${ }^{42}$ identified the association of the common variants in the natriuretic peptide precursor $\mathrm{A}$ and $\mathrm{B}$ genes $(N P P A, N P P B)$ with circulating natriuretic peptide and BP. The second ${ }^{43}$ examined 34433 individuals of European ancestry from the Global BPgen consortium and found that common variants in eight loci were significantly associated with systolic or diastolic BP. In the third paper, ${ }^{44} 10-20$ loci were identified as the candidates responsible for BP and hypertension using the participants of the CHARGE consortium $(n=29136)$. Some of these loci were found to be significantly associated with BP or hypertension in a joint meta-analysis with the Global BPgen Consortium. The final candidate genes obtained from GWAS are listed in Table 2.

\section{ANTIHYPERTENSIVE MEDICATION BASED ON PHARMACOGENOMICS}

Salt sensitivity and genetic predisposition to hypertension are different between races. In the United States, for example, BiDil (isosorbide dinitrate and hydralazine, NitroMed. Inc., Lexington, MA, USA) is currently a standard therapy for African Americans, but not for other races, with heart failure. ${ }^{45}$ Thus, it is not difficult to anticipate that the response to antihypertensive medication also varies greatly between individuals with different racial or genetic backgrounds. Brown ${ }^{46}$ pointed out the function of ethnicity in the pathogenesis of hypertension, and emphasized the usefulness of measuring renin activity in choosing the most appropriate antihypertensive drug. ${ }^{46}$ In this review, age was discussed as a critical modifier in the response to antihypertensive medication. For example, usage of diltiazem or diuretics is recommended for senile African Americans, but not for young Caucasians. In individuals with the salt-sensitive allele of $A D D 1$, diuretic therapy was preferred to reduce the risk of myocardial infarction or stroke compared with other antihypertensive therapies. ${ }^{47}$

Table 2 Candidate hypertensive genes supported by recent genomewide association studies

\begin{tabular}{lll}
\hline Gene symbol & Gene name & Locus \\
\hline NPPA-NPPB & Natriuretic peptide precursor A, B & $1 \mathrm{p} 36.2$ \\
ADD2 & Beta-adducin & $2 \mathrm{p} 14-\mathrm{p} 13$ \\
ULK4 & Unc-51-like kinase 4 (C. elegans) & $3 \mathrm{p} 22.1$ \\
CACNB2 & Calcium channel, voltage-dependent, beta 2 & $10 \mathrm{p} 12$ \\
& subunit \\
CYP17A1 & Cytochrome P450, family 17, subfamily A, & $10 \mathrm{q} 24.3$ \\
& polypeptide 1 & \\
PLEKHA7 & Leckstrin homology domain containing, \\
& family A member 7 & $11 \mathrm{p} 15.1$ \\
M6PR & Mannose-6-phospate \\
ATP2B1 & ATPase, Ca ${ }^{++}$transporting, plasma membrane 1 & $12 \mathrm{q} 21.3$ \\
KIAAO789 & WSC domain containing 2 (WSCD2) & $12 \mathrm{q} 23.3$ \\
TBX3-TBX5 & T-box 3, 5 & $12 \mathrm{q} 24.1$ \\
SH2B3 & SH2B adaptor protein 3 & $12 \mathrm{q} 24$ \\
CSK-ULK3 & C-src tyrosine kinase, unc-51-like kinase 3 & $15 \mathrm{q} 23-\mathrm{q} 25$ \\
& (C. elegans) & \\
CDH13 & H-cadherin (heart) & $16 \mathrm{q} 24.2-\mathrm{q} 24.3$ \\
\hline
\end{tabular}


The racial difference in the response to antihypertensive medication affected the results of major clinical trials, such as the ALLHAT or INSIGHT trial. The genetic background of the participants in ALLHAT was examined as a GenHAT study. It was found that the G-6A polymorphism of AGT was significantly associated with pulse pressure change after 6 months of antihypertensive treatment in a gender-specific manner. ${ }^{48}$ Another interesting result in GenHAT was obtained from the genotype determination of the two polymorphisms in the precursor of the atrial natriuretic polypeptide gene (NPPA). ${ }^{49}$ The C-allele carriers of the NPPA T2238C polymorphism experienced more favorable cardiovascular disease outcomes when randomized to receive a diuretic, whereas the TT-allele carriers had more favorable outcomes when randomized to receive a calcium channel blocker. Most candidate gene polymorphisms, however, did not show any significant association in response to antihypertensive treatment in the GenHAT study.

In contrast, there are many reports suggesting the effect of adrenoceptor gene polymorphisms on $\beta$-blocker treatment, cardiovascular risk and mortality. For example, Pacanowski et al. ${ }^{50}$ reported in the INVEST study that the ADRB1 haplotype variation was associated with mortality risk, and $\beta$-blockers may be preferred in subgroups of patients defined by $\beta 1$ - or $\beta 2$-adrenoceptor gene polymorphisms.

Genome-wide association studies are already incorporated into pharmacogenomic investigations. Turner et al. compared the genetic background between good and poor responders for thiazide diuretic treatment using Affymetrix GeneChip Human Mapping 100K arrays (Affymetrix, Santa Clara, CA, USA). Haplotype trend regression analysis showed that the 12q15 locus was significantly associated with diastolic BP response. ${ }^{51}$ The same group also proposed a new investigation, known as the Pharmacogenomic Evaluation of Antihypertensive Responses (PEAR) study, by recruiting 800 hypertensive individuals and randomizing them to atenorol or hydrochlorothiazide. ${ }^{52}$

In Japan, two major pharmacogenomic cohort studies of antihypertensive therapy are currently in progress. One is the Hypertension Objective Treatment Based on Measurement by Electrical Devices of Blood Pressure (HOMED-BP) Study, which is a large-scale intervention trial using a PROBE design to determine an optimal target BP level on the basis of self-measured BP with an optimal initial dose of antihypertensive medication. ${ }^{53}$ We are carrying out a sub-study of HOMED-BP, known as the HOMED-BP-GENE study, which is a GWAS to examine the genetic background of the response to antihypertensive medication. The preliminary results after a month of treatment suggest that different genes may be responsible for a reduction in BP in the morning and in the evening. Another GWAS is the GEANE (Gene Evaluation for Antihypertensive Effect of drugs) study, which is a multicenter trial to examine the response to a 3-month treatment of diuretics, an angiotensin II receptor blocker and a calcium channel blocker.

\section{CONCLUSIONS}

In comparison with the recent surge of positive results in other common complex diseases, a clear answer has not yet been elucidated for the genetic etiology of hypertension. The continuous efforts of researchers, however, will make progress by small, incremental advances (Figure 1). The chaos observed in hypertension genomics is resolvable by the introduction of new technologies in the place of classical genetic analysis. GWASs, epigenetics, pharmacogenomics and accurate phenotyping of clinical features (for example, home BP measurement) are issues that are critical to the success of investigations. In addition, fresh ideas are also crucial in finding a novel way to clarify the pathogenesis of hypertension. To consider

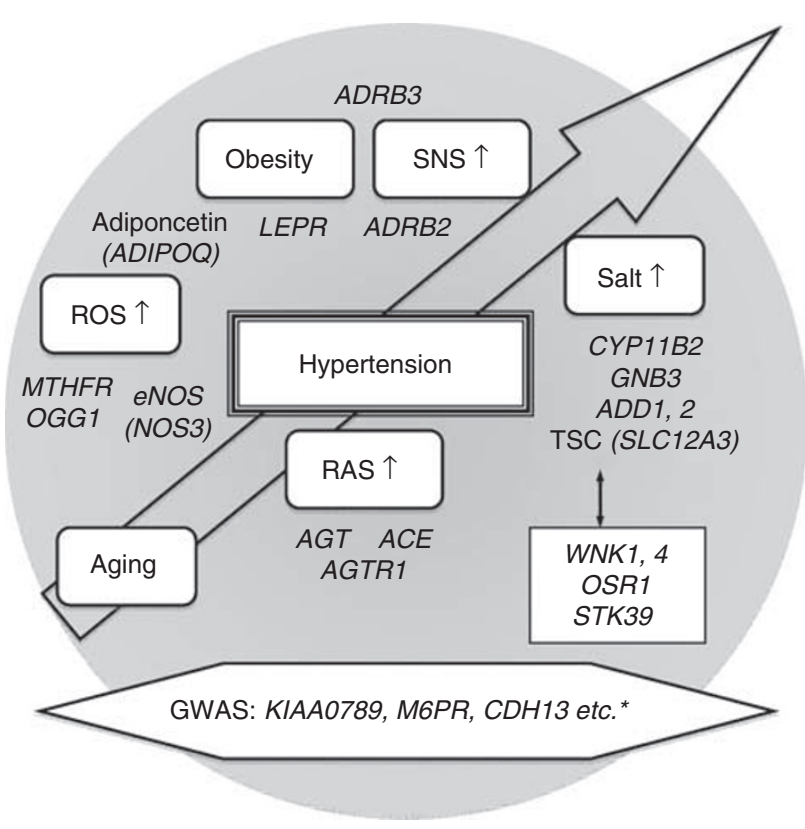

Figure 1 Prevalence of hypertension increases with age. Various genes, indicated in italics as gene symbols, affect the onset and development of hypertension. *Other candidate genes from GWAS are listed in Table 2. SNS, sympathetic nervous system; ROS, reactive oxygen species; RAS, renin-angiotensin system, GWAS, genome-wide association study. Gene symbols: $L E P R$, leptin receptor; $A D R B 2$, beta-2-adrenergic receptor; $A D R B 3$, beta-3-adrenergic receptor; $M T H F R, 5,10$-methlenetetrahydrofolate reductase; OGG1, 8-oxoguanine DNA glycosylase; CYP11B2, cytochrome P450, subfamily $Y X I B$, polypeptide 2; GNB3, guanine nucleotide-binding protein, beta-3; ADD1, alpha-adducin; ADD2, beta-adducin; SLC12A3, solute carrier family 12 (sodium-chloride transporter), member 3; WNK1, protein kinase, lysine-deficient 1; WNK4, protein kinase, lysine-deficient 4; STK39, serine/threonine protein kinase 39; $A G T$, angiotensinogen; $A C E$, angiotensin I-converting enzyme (peptidyl-dipeptidase A) 1; AGTR1, angiotensin II receptor, type 1; KIAA0789 (WSCD2), WSC domain containing 2; M6PR, mannose-6-phosphate receptor (cation dependent); CDH13, cadherin 13 (H-cadherin (heart)).

hypertension from the viewpoint of aging, arteriosclerosis and volume retention, paying close attention to salt sensitivity, the renin-angiotensin system, atherosclerosis, ROS and sympathetic nerve activation, as well as cell growth, apoptosis, immune reaction and adipocyte differentiation, could be the solution for resolving hypertension genomics.

\section{CONFLICT OF INTEREST}

The authors declare no conflict of interest.

\section{ACKNOWLEDGEMENTS}

The authors thank Ms. Kazuko Iwasa and Ms. Eriko Nagata for their continuous support to our investigations. The authors also thank all collaborators and participants of the Ohasama Study, the Tanno-Sobetsu Study, the Amagasaki Study, the Suita Study, the HOMED-BP-GENE Study and the Hypertension Task Force of the Japanese Millennium Genome Project (Chief: Professor Tetsuro Miki). Our previous investigations were supported by a Grant-in-Aid for Scientific Research (H17-pharmaco-common-003) from the Japanese Ministry of Health, Labor, and Welfare, Grants-in-Aid for Scientific Research (18590265, 18590811, 19650188, 21390223) from the Ministry of Education, Science, Sports and Culture of Japan and by research grants from the Japan Research Foundation for Clinical Pharmacology. 
1 Ogihara T, Kikuchi K, Matsuoka H, Fujita T, Higaki J, Horiuchi M, Imai Y, Imaizumi T, Ito $\mathrm{S}$, Iwao $\mathrm{H}$, Kario K, Kawano Y, Kim-Mitsuyama S, Kimura G, Matsubara H, Matsuura H, Naruse M, Saito I, Shimada K, Shimamoto K, Suzuki H, Takishita S, Tanahashi N, Tsuchihashi T, Uchiyama M, Ueda S, Ueshima H, Umemura S, Ishimitsu T, Rakugi H. The Japanese Society of Hypertension Guidelines for the Management of Hypertension (JSH 2009). Hypertens Res 2009; 32: 3-107.

2 Brown MJ. The causes of essential hypertension. Br J Clin Pharmacol 1996; 42 21-27.

3 Pilia G, Chen WM, Scuteri A, Orru M, Albai G, Dei M, Lai S, Usala G, Lai M, Loi P, Mameli C, Vacca L, Deiana M, Olla N, Masala M, Cao A, Najjar SS, Terracciano A, Nedorezov T, Sharov A, Zonderman AB, Abecasis GR, Costa P, Lakatta E, Schlessinger D. Heritability of cardiovascular and personality traits in 6,148 Sardinians. PLoS Genet 2006; 2: e132.

4 Ji W, Foo JN, O'Roak BJ, Zhao H, Larson MG, Simon DB, Newton-Cheh C, State MW, Levy $D$, Lifton RP. Rare independent mutations in renal salt handling genes contribute to blood pressure variation. Nat Genet 2008; 40: 592-599.

5 Wagner CA. How much is blood pressure in the general population determined by rare mutations in renal salt-transporting proteins? J Nephrol 2008; 21: 632-634.

6 Katsuya T, Koike G, Yee TW, Sharpe N, Jackson R, Norton R, Horiuchi M, Pratt RE, Dzau $\mathrm{VJ}$, MacMahon S. Association of angiotensinogen gene T235 variant with increased risk of coronary heart disease. Lancet 1995; 345: 1600-1603.

7 Fujiwara T, Katsuya T, Matsubara M, Mikami T, Ishikawa K, Kikuya M, Ohkubo T, Hozawa A, Michimata M, Suzuki M, Metoki H, Asayama K, Araki T, Tsuji I, Higaki J, Satoh H, Hisamichi S, Ogihara T, Imai Y. T+31C polymorphism of angiotensinogen gene and nocturnal blood pressure decline: the Ohasama study. Am J Hypertens 2002; 15: 628-632.

8 Katsuya T, Ishikawa K, Sugimoto K, Rakugi H, Ogihara T. Salt sensitivity of Japanese from the viewpoint of gene polymorphism. Hypertens Res 2003; 26: 521-525.

9 Hunt SC, Cook NR, Oberman A, Cutler JA, Hennekens CH, Allender PS, Walker WG, Whelton PK, Williams RR. Angiotensinogen genotype, sodium reduction, weight loss, and prevention of hypertension: trials of hypertension prevention, phase II. Hypertension 1998; 32: 393-401.

10 Kokubo Y, Kamide K, Inamoto N, Tanaka C, Banno M, Takiuchi S, Kawano Y, Tomoike $\mathrm{H}$, Miyata T. Identification of 108 SNPs in TSC, WNK1, and WNK4 and their association with hypertension in a Japanese general population. J Hum Genet 2004, 49: $507-515$

11 Matsuo A, Katsuya T, Ishikawa K, Sugimoto K, Iwashima Y, Yamamoto K, Ohishi M, Rakugi $\mathrm{H}$, Ogihara T. G2736A polymorphism of thiazide-sensitive $\mathrm{Na}-\mathrm{Cl}$ cotransporter gene predisposes to hypertension in young women. J Hypertens 2004; 22 2123-2127.

12 Matayoshi T, Kamide K, Takiuchi S, Yoshii M, Miwa Y, Takami Y, Tanaka C, Banno M Horio T, Nakamura S, Nakahama H, Yoshihara F, Inenaga T, Miyata T, Kawano Y. The thiazide-sensitive $\mathrm{Na}(+)-\mathrm{Cl}(-)$ cotransporter gene, C1784T, and adrenergic receptorbeta3 gene, T727C, may be gene polymorphisms susceptible to the antihypertensive effect of thiazide diuretics. Hypertens Res 2004; 27: 821-833.

13 Keszei AP, Tisler A, Backx PH, Andrulis IL, Bull SB, Logan AG. Molecular variants of the thiazide-sensitive $\mathrm{Na}+-\mathrm{Cl}$ - cotransporter in hypertensive families. J Hypertens 2007; 25: 2074-2081.

14 Ogihara T, Katsuya T, Ishikawa K, Matsuo A, Rakugi H, Shoji M, Yasujima M. Hypertension in a patient with Gitelman's syndrome. J Hum Hypertens 2004; 18: 677-679.

15 Wilson FH, Disse-Nicodeme S, Choate KA, Ishikawa K, Nelson-Williams C, Desitter I, Gunel M, Milford DV, Lipkin GW, Achard JM, Feely MP, Dussol B, Berland Y, Unwin RJ, Mayan H, Simon DB, Farfel Z, Jeunemaitre X, Lifton RP. Human hypertension caused by mutations in WNK kinases. Science 2001; 293: 1107-1112.

16 Huang CL, Yang SS, Lin SH. Mechanism of regulation of renal ion transport by WNK kinases. Curr Opin Nephrol Hypertens 2008; 17: 519-525.

17 San-Cristobal P, Ponce-Coria J, Vazquez N, Bobadilla NA, Gamba G. WNK3 and WNK4 amino-terminal domain defines their effect on the renal $\mathrm{Na}+\mathrm{Cl}$ - cotransporter. Am J Physiol Renal Physiol 2008; 295: F1199-F1206.

18 Wang Y, O'Connell JR, McArdle PF, Wade JB, Dorff SE, Shah SJ, Shi X, Pan L, Rampersaud E, Shen H, Kim JD, Subramanya AR, Steinle NI, Parsa A, Ober CC, Welling PA, Chakravarti A, Weder AB, Cooper RS, Mitchell BD, Shuldiner AR, Chang YP. From the cover: whole-genome association study identifies STK39 as a hypertension susceptibility gene. Proc Natl Acad Sci USA 2009; 106: 226-231.

19 Iwai M, Horiuchi M. Role of renin-angiotensin system in adipose tissue dysfunction. Hypertens Res 2009; 32: 425-427.

20 Julius S, Nesbitt SD, Egan BM, Weber MA, Michelson EL, Kaciroti N, Black HR, Grimm Jr RH, Messerli FH, Oparil S, Schork MA. Feasibility of treating prehypertension with an angiotensin-receptor blocker. N Engl J Med 2006; 354: 1685-1697.

21 Takase H, Dohi Y, Toriyama T, Okado T, Tanaka S, Sato K, Kimura G. Metabolic disorders predict development of hypertension in normotensive Japanese subjects. Hypertens Res 2008; 31: 665-671.

22 Iwashima Y, Katsuya T, Ishikawa K, Ouchi N, Ohishi M, Sugimoto K, Fu Y, Motone M, Yamamoto K, Matsuo A, Ohashi K, Kihara S, Funahashi T, Rakugi H, Matsuzawa Y, Ogihara T. Hypoadiponectinemia is an independent risk factor for hypertension. Hypertension 2004; 43: 1318-1323.

23 Puddu P, Puddu GM, Cravero E, Rosati M, Muscari A. The molecular sources of reactive oxygen species in hypertension. Blood Press 2008; 17: 70-77.

24 Suzuki S, Yoshimura M, Nakayama M, Abe K, Yamamuro M, Nagayoshi Y, Kojima S, Kaikita K, Sugiyama S, Yasue H, Ogawa H. A novel genetic marker for coronary spasm in women from a genome-wide single nucleotide polymorphism analysis. Pharmacogenet Genomics 2007; 17: 919-930.

25 Katsuya T, Sugimoto K, Hozawa A, Ohkubo T, Yamamoto K, Matsuo A, Ishikawa K, Matsubara H, Rakugi H, Tsuji I, Imai Y, Ogihara T. Genetic risk factors for cerebral infarction using data from a large scale genetic epidemiological study: the Ohasama Study. Geriatr Gerontol Int 2003; 3: 150-153.

26 Inamoto N, Katsuya T, Kokubo Y, Mannami T, Asai T, Baba S, Ogata J, Tomoike H, Ogihara T. Association of methylenetetrahydrofolate reductase gene polymorphism with carotid atherosclerosis depending on smoking status in a Japanese general population. Stroke 2003; 34: 1628-1633.

27 Nakamura T, Yamamoto E, Kataoka K, Yamashita T, Tokutomi Y, Dong YF, Matsuba S, Ogawa H, Kim-Mitsuyama S. Beneficial effects of pioglitazone on hypertensive cardiovascular injury are enhanced by combination with candesartan. Hypertension 2008; 51: 296-301.

28 Masuo K, Katsuya T, Fu Y, Rakugi H, Ogihara T, Tuck ML. Beta2- and beta3-adrenergic receptor polymorphisms are related to the onset of weight gain and blood pressure elevation over 5 years. Circulation 2005; 111: 3429-3434.

29 Masuo K, Katsuya T, Sugimoto K, Kawaguchi H, Rakugi H, Ogihara T, Tuck ML. High plasma norepinephrine levels associated with beta2-adrenoceptor polymorphisms predict future renal damage in nonobese normotensive individuals. Hypertens Res 2007; 30: 503-511.

30 Masuo K, Straznicky NE, Lambert GW, Katsuya T, Sugimoto K, Rakugi H, Socratous F, Hastings J, Lambert EA, Ogihara T, Esler MD. Leptin-receptor polymorphisms relate to obesity through blunted leptin-mediated sympathetic nerve activation in a Caucasian male population. Hypertens Res 2008; 31: 1093-1100.

31 Kawaguchi H, Masuo K, Katsuya T, Sugimoto K, Rakugi H, Ogihara T, Tuck ML. Beta2- and beta3-adrenoceptor polymorphisms relate to subsequent weight gain and blood pressure elevation in obese normotensive individuals. Hypertens Res 2006; 29: 951-959.

32 Wellcome Trust Case Control Consortium. Genome-wide association study of 14,000 cases of seven common diseases and 3,000 shared controls. Nature 2007; 447: 661-678.

33 Browning BL, Browning SR. Haplotypic analysis of Wellcome Trust Case Control Consortium data. Hum Genet 2008; 123: 273-280.

34 Ehret GB, Morrison AC, O'Connor AA, Grove ML, Baird L, Schwander K, Weder A, Cooper RS, Rao DC, Hunt SC, Boerwinkle E, Chakravarti A. Replication of the Wellcome Trust genome-wide association study of essential hypertension: the Family Blood Pressure Program. Eur J Hum Genet 2008; 16: 1507-1511.

35 Shi G, Gu CC, Kraja AT, Arnett DK, Myers RH, Pankow JS, Hunt SC, Rao DC. Genetic effect on blood pressure is modulated by age: the Hypertension Genetic Epidemiology Network Study. Hypertension 2009; 53: 35-41.

36 Yatsu K, Mizuki N, Hirawa N, Oka A, Itoh N, Yamane T, Ogawa M, Shiwa T, Tabara Y, Ohno S, Soma M, Hata A, Nakao K, Ueshima H, Ogihara T, Tomoike H, Miki T, Kimura A, Mano S, Kulski JK, Umemura S, Inoko H. High-resolution mapping for essential hypertension using microsatellite markers. Hypertension 2007; 49: 446-452.

37 Kato N, Miyata T, Tabara Y, Katsuya T, Yanai K, Hanada H, Kamide K, Nakura J, Kohara K, Takeuchi F, Mano H, Yasunami M, Kimura A, Kita Y, Ueshima H, Nakayama T, Soma M, Hata A, Fujioka A, Kawano Y, Nakao K, Sekine A, Yoshida T, Nakamura Y, Saruta T, Ogihara T, Sugano S, Miki T, Tomoike H. High-density association study and nomination of susceptibility genes for hypertension in the Japanese National Project. Hum $\mathrm{Mol}$ Genet 2008; 17: 617-627.

38 Org E, Eyheramendy S, Juhanson P, Gieger C, Lichtner P, Klopp N, Veldre G, Doring A, Viigimaa M, Sober S, Tomberg K, Eckstein G, Kelgo P, Rebane T, Shaw-Hawkins S, Howard P, Onipinla A, Dobson RJ, Newhouse SJ, Brown M, Dominiczak A, Connell J, Samani N, Farrall M, Caulfield MJ, Munroe PB, Illig T, Wichmann HE, Meitinger T, Laan M. Genome-wide scan identifies $\mathrm{CDH} 13$ as a novel susceptibility locus contributing to blood pressure determination in two European populations. Hum Mol Genet 2009; 18: 2288-2296.

39 Hug C, Wang J, Ahmad NS, Bogan JS, Tsao TS, Lodish HF. T-cadherin is a receptor for hexameric and high-molecular-weight forms of Acrp30/adiponectin. Proc Natl Acad Sci USA 2004; 101: 10308-10313.

40 Brock MV, Hooker CM, Ota-Machida E, Han Y, Guo M, Ames S, Glockner S, Piantadosi S, Gabrielson E, Pridham G, Pelosky K, Belinsky SA, Yang SC, Baylin SB, Herman JG. DNA methylation markers and early recurrence in stage I lung cancer. $N$ Engl J Med 2008; 358: 1118-1128.

41 Samani NJ, Erdmann J, Hall AS, Hengstenberg C, Mangino M, Mayer B, Dixon RJ, Meitinger T, Braund P, Wichmann HE, Barrett JH, Konig IR, Stevens SE, Szymczak S, Tregouet DA, Iles MM, Pahlke F, Pollard H, Lieb W, Cambien F, Fischer M, Ouwehand W, Blankenberg S, Balmforth AJ, Baessler A, Ball SG, Strom TM, Braenne I, Gieger C, Deloukas P, Tobin MD, Ziegler A, Thompson JR, Schunkert H. Genomewide association analysis of coronary artery disease. N Engl J Med 2007; 357: 443-453.

42 Newton-Cheh C, Larson MG, Vasan RS, Levy D, Bloch KD, Surti A, Guiducci C, Kathiresan S, Benjamin EJ, Struck J, Morgenthaler NG, Bergmann A, Blankenberg S, Kee F, Nilsson P, Yin X, Peltonen L, Vartiainen E, Salomaa V, Hirschhorn JN, Melander 0 , Wang TJ. Association of common variants in NPPA and NPPB with circulating natriuretic peptides and blood pressure. Nat Genet 2009; 41: 348-353.

43 Newton-Cheh C, Johnson T, Gateva V, Tobin MD, Bochud M, Coin L, Najjar SS, Zhao JH, Heath SC, Eyheramendy S, Papadakis K, Voight BF, Scott LJ, Zhang F, Farrall M, Tanaka T, Wallace C, Chambers JC, Khaw KT, Nilsson P, van der Harst P, Polidoro S, Grobbee DE, Onland-Moret NC, Bots ML, Wain LV, Elliott KS, Teumer A, Luan J, Lucas G, Kuusisto J, Burton PR, Hadley D, McArdle WL, Brown M, Dominiczak A, Newhouse SJ, Samani NJ, Webster J, Zeggini E, Beckmann JS, Bergmann S, Lim N, Song K, Vollenweider P, Waeber G, Waterworth DM, Yuan X, Groop L, Orho-Melander M, Allione 
A, Di Gregorio A, Guarrera S, Panico S, Ricceri F, Romanazzi V, Sacerdote C, Vineis P, Barroso I, Sandhu MS, Luben RN, Crawford GJ, Jousilahti P, Perola M, Boehnke M, Bonnycastle LL, Collins FS, Jackson AU, Mohlke KL, Stringham HM, Valle TT, Willer CJ, Bergman RN, Morken MA, Doring A, Gieger C, IIIig T, Meitinger T, Org E, Pfeufer A, Wichmann HE, Kathiresan S, Marrugat J, O'Donnell CJ, Schwartz SM, Siscovick DS, Subirana I, Freimer NB, Hartikainen AL, McCarthy MI, O'Reilly PF, Peltonen L, Pouta A, de Jong PE, Snieder $H$, van Gilst WH, Clarke R, Goel A, Hamsten A, Peden JF, Seedorf U, Syvanen AC, Tognoni G, Lakatta EG, Sanna S, Scheet P, Schlessinger D, Scuteri A, Dorr M, Ernst F, Felix SB, Homuth G, Lorbeer R, Reffelmann T, Rettig R, Volker U, Galan P, Gut IG, Hercberg S, Lathrop GM, Zelenika D, Deloukas P, Soranzo N, Williams FM, Zhai G, Salomaa V, Laakso M, Elosua R, Forouhi NG, Volzke H, Uiterwaal CS, van der Schouw YT, Numans ME, Matullo G, Navis G, Berglund G, Bingham SA, Kooner JS, Connell JM, Bandinelli S, Ferrucci L, Watkins H, Spector TD, Tuomilehto J, Altshuler D, Strachan DP, Laan M, Meneton P, Wareham NJ, Uda M, Jarvelin MR, Mooser V, Melander O, Loos RJ, Elliott P, Abecasis GR, Caulfield M, Munroe PB. Genome-wide association study identifies eight loci associated with blood pressure. Nat Genet 2009; 41: 666-676.

44 Levy D, Ehret GB, Rice K, Verwoert GC, Launer LJ, Dehghan A, Glazer NL, Morrison AC, Johnson AD, Aspelund T, Aulchenko Y, Lumley T, Kottgen A, Vasan RS, Rivadeneira F, Eiriksdottir G, Guo X, Arking DE, Mitchell GF, Mattace-Raso FU, Smith AV, Taylor K, Scharpf RB, Hwang SJ, Sijbrands EJ, Bis J, Harris TB, Ganesh SK, O'Donnell CJ, Hofman A, Rotter JI, Coresh J, Benjamin EJ, Uitterlinden AG, Heiss G, Fox CS, Witteman JC, Boerwinkle E, Wang TJ, Gudnason V, Larson MG, Chakravarti A, Psaty BM, van Duijn CM. Genome-wide association study of blood pressure and hypertension. Nat Genet 2009; 41: 677-687.

45 Tutton R, Smart A, Martin PA, Ashcroft R, Ellison GT. Genotyping the future: scientists' expectations about race/ethnicity after BiDil. J Law Med Ethics 2008; 36: 464-470.
46 Brown MJ. Hypertension and ethnic group. BMJ 2006; 332: 833-836.

47 Psaty BM, Smith NL, Heckbert SR, Vos HL, Lemaitre RN, Reiner AP, Siscovick DS, Bis J, Lumley T, Longstreth Jr WT, Rosendaal FR. Diuretic therapy, the alpha-adducin gene variant, and the risk of myocardial infarction or stroke in persons with treated hypertension. JAMA 2002; 287: 1680-1689.

48 Lynch AI, Arnett DK, Davis BR, Boerwinkle E, Ford CE, Eckfeldt JH, Leiendecker-Foster C. Sex-specific effects of AGT- 6 and ACE I/D on pulse pressure after 6 months on antihypertensive treatment: the GenHAT study. Ann Hum Genet 2007; 71: 735-745.

49 Lynch Al, Boerwinkle E, Davis BR, Ford CE, Eckfeldt JH, Leiendecker-Foster C, Arnett DK. Pharmacogenetic association of the NPPA T2238C genetic variant with cardiovascular disease outcomes in patients with hypertension. JAMA 2008; 299: 296-307.

50 Pacanowski MA, Gong Y, Cooper-Dehoff RM, Schork NJ, Shriver MD, Langaee TY, Pepine CJ, Johnson JA. Beta-adrenergic receptor gene polymorphisms and beta-blocker treatment outcomes in hypertension. Clin Pharmacol Ther 2008; 84: 715-721.

51 Turner ST, Bailey KR, Fridley BL, Chapman AB, Schwartz GL, Chai HS, Sicotte H, Kocher JP, Rodin AS, Boerwinkle E. Genomic association analysis suggests chromosome 12 locus influencing antihypertensive response to thiazide diuretic. Hypertension 2008; 52: 359-365.

52 Johnson JA, Boerwinkle E, Zineh I, Chapman AB, Bailey K, Cooper-DeHoff RM, Gums J, Curry RW, Gong Y, Beitelshees AL, Schwartz G, Turner ST. Pharmacogenomics of antihypertensive drugs: rationale and design of the Pharmacogenomic Evaluation of Antihypertensive Responses (PEAR) study. Am Heart J 2009; 157: 442-449.

53 Hosohata K, Saito S, Asayama K, Ohkubo T, Kikuya M, Metoki H, Obara T, Kato T, Hashimoto J, Totsune K, Miura Y, Imai Y, The H-BPSG. Progress report on The Hypertension Objective Treatment Based on Measurement by Electrical Devices of Blood Pressure (HOMED-BP) study: status at February 2004. Clin Exp Hypertens 2007; 29: 69-81. 